Abstracta Iranicacta Iranica

Revue bibliographique pour le domaine irano-aryen

Volume 28 | 2007

Comptes rendus des publications de 2005

\title{
« Dancing Diamonds, In Memory of P.R.S. Moorey ». Iran, XLIII, 2005, pp. 117-133.
}

\section{Aurélie Daems}

\section{(2) OpenEdition}

1 Journals

\section{Édition électronique}

URL : http://journals.openedition.org/abstractairanica/15752

DOI : 10.4000/abstractairanica. 15752

ISSN : 1961-960X

Éditeur :

CNRS (UMR 7528 Mondes iraniens et indiens), Éditions de l'IFRI

\section{Édition imprimée}

Date de publication : 15 mai 2007

ISSN : 0240-8910

\section{Référence électronique}

Aurélie Daems, « «Dancing Diamonds, In Memory of P.R.S. Moorey ». Iran, XLIII, 2005, pp. 117-133. », Abstracta Iranica [En ligne], Volume 28 | 2007, document 85, mis en ligne le 18 septembre 2007,

consulté le 25 septembre 2020. URL : http://journals.openedition.org/abstractairanica/15752 ; DOI : https://doi.org/10.4000/abstractairanica.15752

Ce document a été généré automatiquement le 25 septembre 2020.

Tous droits réservés 
« Dancing Diamonds, In Memory of P.R.S. Moorey ». Iran, XLIII, 2005, pp. 117-133.

Aurélie Daems 
1 As much as I do embrace any attempt at elucidating the hidden meaning of any man made artefact or image, Garfinkel's interpretation of diamond shaped motives on a selected sample of proto-historic Iranian sherds feels like a bridge too far. A set of Susiana Black on Buff sherds from Luristan to Kerman is subjected to a very scrutinised, balanced stylistic analysis but sadly only effectuated in order to support a preconceived idea of net-covered and plain diamonds 'with limbs' (p. 121 onwards) as being abstract representations of people dancing during a ceremony (p. 131). The connection between the images and the conclusion made by the author is not transparent enough in the article. The diamonds are dancing; for a fact, but the supporting/comparative evidence is too meagre; at least to me. There is the problem of fragmentation of the Bakun sherds, of the Nevali Çori sherd having no connection with the material discussed (in time, in space) and of the problematic Giyan seal (see c.r. $n^{\circ} 48$ ) who described the many problems with which the seals from Giyan are concerned; one of them being that Herzfeld's drawings of the seals often do not match the original seal's scenery! (and Garfinkel relies on the drawing here). We are also guided to other references that support the dancing statement but these are mainly prior works made by the author - and arguments are not repeated here. I am not saying Garfinkel is wrong: the interpretation put forward is an interesting and alluring one certainly worth acknowledging but I would have preferred 'dancing' as one of several suggested interpretations rather than as a clear-cut fact. The only sherds that may indeed be abstract representations of people (but even then it should not necessarily be during a dance) are the ones from Kozagaran, since there are more supporting arguments here. Overall the study is a thorough, interesting and elaborate one, but it is a pity the abstraction of a human is taken as a fact / certainty throughout the article rather than as a suggestion enforced by strong arguments.

\section{INDEX}

Thèmes : 3.2.2. Pré-Achéménides et Achéménides

\section{AUTEURS}

\section{AURÉLIE DAEMS}

Paris 